\title{
Leucaena leucocephala: A Fast-growing Tree for the Malaysian Particleboard Industry
}

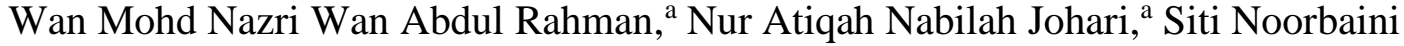 \\ Sarmin, ${ }^{a}$ Nor Yuziah Mohd Yunus, ${ }^{\mathrm{a}, *}$ Yani Japarudin,,${ }^{\mathrm{b}}$ Jamaluddin Mahmud, ${ }^{\mathrm{c}}$ and \\ Mohd Nizar Khairuddin ${ }^{\mathrm{d}}$
}

\begin{abstract}
Leucaena leucocephala (Lam) de Wit is a fast-growing tree species often used as lead (shade) tree that can be cultivated in Malaysia. This species has potential as an alternative resource for the Malaysian furniture and panel board industries in the coming years because of a shortage of the current frequently used raw material (rubberwood). A study on growth performance and potential as particleboard resource material was done. In terms of growth performance, the preliminary study indicated that Leucaena trees grew at a rate of $44 \%$ from the first month to the forth month and $43 \%$ from 6 to 12 months. As for particleboard manufacturing, Leucaena: Rubberwood admixture bound with urea formaldehyde $(8 \%, 10 \%$ and $12 \%$ resin content) to a density of 700 $\mathrm{kg} / \mathrm{m}^{3}$, showed promise of usability when all boards pass the Type P2 board requirement of EN312:2010. In general, L. leucocephala wood is a potential raw material for the manufacture of wood composites.
\end{abstract}

Keywords: Growth rate; Leucaena leucocephala; Particleboard; Particle ratio; Resin content

Contact information: a: Faculty of Applied Sciences, Universiti Teknologi MARA Pahang, 26400 Bandar Tun Abdul Razak Jengka, Pahang, Malaysia; b: Sabah Softwoods Berhad, km 8, Jalan Sin San, Pasir Putih, P.O. Box 60966, 91019 Tawau, Sabah, Malaysia; c: Faculty of Mechanical Engineering, Universiti Teknologi MARA 40450 Shah Alam, Selangor, Malaysia; $d$ : FGV R\&D, Pusat Penyelidikan Pertanian Tun Razak, 26400 Bandar Tun Abdul Razak Jengka, Pahang, Malaysia;

* Corresponding author: noryuziah@ uitm.edu.my

\section{INTRODUCTION}

The growing demands for wood-based products have led to continuous efforts in finding alternative resources for production to provide a balance between supply and demand. Zhang et al. (2011) mentioned that the demand for wood-based panel products, such as particleboard, medium density fiberboard (MDF), and plywood, has increased substantially throughout the world, in tandem with population growth. In the last two decades, the wood-based industry has become one of the most important socio-economic sectors in Malaysia.

Consequently, wood product manufacturers in Malaysia are exhausting the supply of good quality timber. In Peninsular Malaysia, the sources of raw material for the wood composite industry are mainly wood residues and rubberwood. The successful conversion of rubberwood to panels and furniture, in conjunction with declining re-plantation areas of rubber tree (replaced with oil palm tree, Anis et al. 2014), has put a great stress on the support of this raw material. To ensure a sustainable supply of feed stock, a fast-growing species needs to be introduced to sustain the demand of the wood industry sector in Malaysia. According to Ishak et al. (2013), fast growing trees could be used as an alternative raw material in the production of particleboard, MDF, and chipboard. As fast 
growing tree species have become a popular plantation forest commodity in Malaysia and other Asian countries, many studies have been conducted to consider their properties and possible utilization. Attempts on particleboard making with fast growing species has been done by Wan Abd Rahman et al. (2019) using Neolamarckia and Leucaena (Loh et al. 2010) with rubberwood and Mahang, Sarmin et al. (2013) with saw dust and Acacia, and Kassim et al. (2008) on Sesendok. Muhammad Fitri et al. (2019) reported a successful commercial trial using Leucaena and rubberwood. The use of a fast-growing species for wood composite production may offer some advantages, such as a shorter time required to activate production compared with other woody plants (Oggiano et al. 1997). Shorter forest management periods and rotational plantations have been practiced to cope with the problem of raw material shortage (Guler et al. 2007). These methods also protect natural resources, such as soil, water, and wildlife (Ashori and Nourbakhsh 2008).

To identify and enhance Leucaena tree suitability as particleboard resource a twoprong study was done. First, the growth performance of Leucaena was assessed over a period of 12 months. Secondly, the conversion of planted 18-months-old Leucaena tree to particleboard at selected Leucaena: rubberwood and resin level was done.

\section{EXPERIMENTAL}

\section{Materials and Methods}

This study involved two parts: i.) tree growth performance measurement, and ii.) particleboard manufacturing.

The study on the growth rate was conducted at Brumas Estate, Tawau, Malaysia. Brumas is located at a longitude of $117^{\circ} 43^{\prime} \mathrm{E}$ and latitude of $4^{\circ} 35^{\prime} \mathrm{N}$. It is approximately $75 \mathrm{~km}$ from the town of Tawau and $244 \mathrm{~m}$ above sea level. The climate is typically warm and wet with a mean minimum temperature of $22{ }^{\circ} \mathrm{C}$ (night) and maximum temperature of $33{ }^{\circ} \mathrm{C}$ as recorded on site. The selected area is a managed forest research station. During the nursery stage, the study used 77 cells per tray. Seedling germination was done in the shade three to four weeks prior to exposure to sunlight.

To assess the plant growth performance, measurements of the diameter $1 \mathrm{ft}$ above ground level, height from the ground to shoot tip, and tree survival rate were recorded. The growth performance was analyzed based on the quantitative height and survival rate made at the ages of 1 month, 2 months, 4 months, 6 months, and 12 months.

Suitability of conversion to particleboard was tested on Leucaena aged 18 months. The trees were collected from Educational Forest of Universiti Teknologi MARA, Pahang, Malaysia. The stems of the Leucaena trees were collected $0.2 \mathrm{~m}$ above the ground up to a diameter of $3 \mathrm{~cm}$ (about $3 \mathrm{~m}$ ). The stems were debarked, chipped to 50 $\mathrm{mm}$ billets, and then flaked. The prepared particles were air dried for a week and screened to remove oversized $(>20 \mathrm{~mm})$ and undersize $(<0.5 \mathrm{~mm})$ particles. Rubberwood particles were collected from local particleboard manufacturer, air dried, and screened as per Leucaena. Both particles were oven dried to below 5\% moisture content prior to blending. Particles were weighted and pre-mixed according to particle ratio requirement before resin addition. Upon complete addition of resin, the resinated particles were allowed to mix for a further $15 \mathrm{~min}$. Resinated particles were then formed in a mould and cold pressed for $20 \mathrm{~min}$. Then boards were hot pressed at $165^{\circ} \mathrm{C}$, with a press cycle of $1800 \rightarrow 1200 \rightarrow 600 \mathrm{psi}$, for $3 \rightarrow 2 \rightarrow 1 \mathrm{~min}$, respectively. Three ratios of Leucaena leucocephala: rubberwood (LL:R) of 20:80, 50:50, and 80:20 was used. Homogenous 
single layer particleboard of $12 \mathrm{~mm}$ thickness with density of $700 \mathrm{~kg} / \mathrm{m}^{3}$ was prepared in triplicate. Urea formaldehyde suitable for E1 board was used. The resin has $64 \%$ solid content, $\mathrm{pH}$ of 7.8 to 8.2 , viscosity range of 1.8 to 2.2 poise, and gelation time of 80 to 90 sec using $1.5 \%$ hardener, ammonium chloride. Boards were prepared using three resin contents $(8 \%, 10 \%$, and 12\%). The physical (thickness swelling (TS) and water absorption (WA) properties and mechanical properties (modulus of elasticity (MOE), modulus of rupture (MOR), and internal bonding (IB)) of the particleboards were tested to establish the particleboard performance in accordance with the EN310, EN317, and EN319 standards. The factors affecting particleboard manufacturing were analysed using the IBM Statistical Package (Armonk, USA). Figure 1 shows the experimental design for the board test, Level 1 showing the particle ratio and Level 2 the resin dosage.

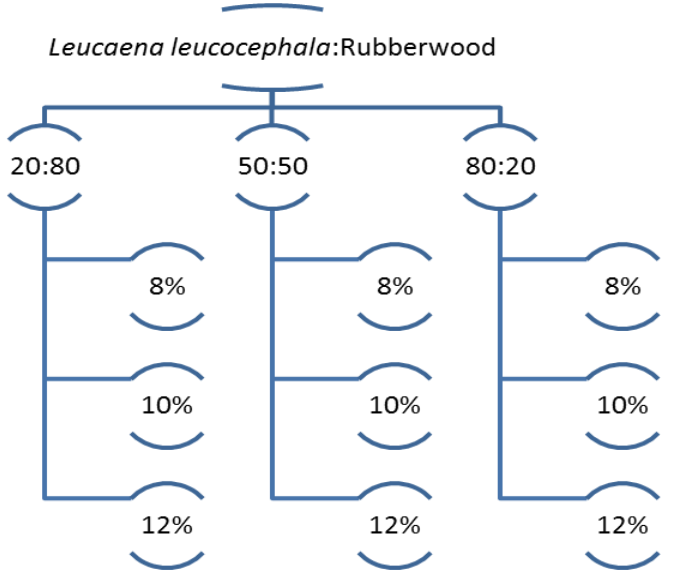

Fig. 1. Particleboard experimental design

\section{RESULTS AND DISCUSSION}

\section{Growth Study}

Growth is the biological phenomenon of an increase in size with time. The relationships of the tree size to the age and the increment to the age are important for predicting future growth. The means for all of the trees assessed for tree height according to the age are given in Fig. 2. Generally, the performance of the preliminary study indicated that Leucaena trees grew at a rate of $44 \%$ from 1 month to 4 months. However, it was expected that the tree height would increase if the planting distance of $3 \mathrm{~m} \times 3 \mathrm{~m}$ used during the trial was reduced to $1 \mathrm{~m} \times 1 \mathrm{~m}$ or less. It was observed that with a planting distance of $3 \mathrm{~m} \times 3 \mathrm{~m}$, the Leucaena trees planted in the field sagged and grew according to the wind direction, which indicated that young Leucaena trees need to be supported until they are larger in size. The species has a better growth potential and can hopefully produce more woody material at a more matured stage.

The means for all of the trees assessed for the tree height according to the age showed positive height growth rates (Fig. 3). After 12 months, the trees reached a height of more than $3 \mathrm{~m}$. Generally, the growth performance study indicated that the Leucaena tree height had a $43 \%$ growth rate from 6 months to 12 months. 


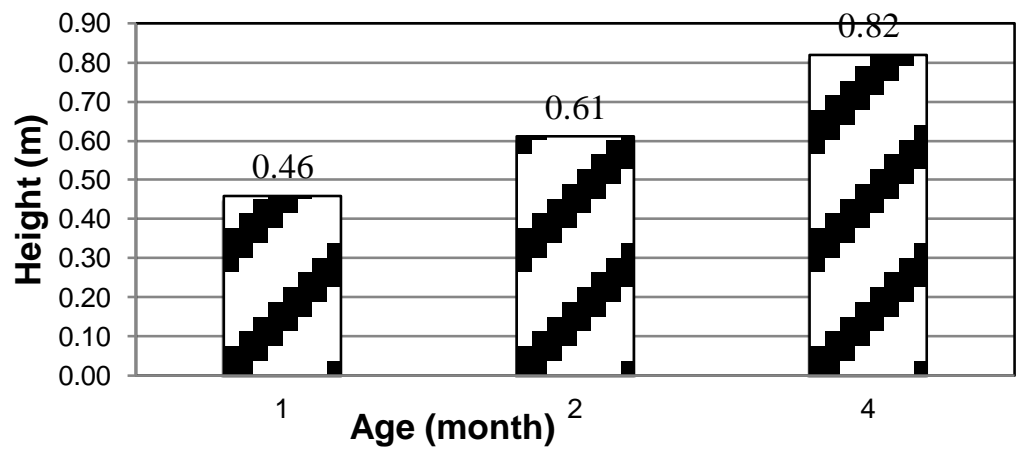

Fig. 2. Height development of Leucaena seedling

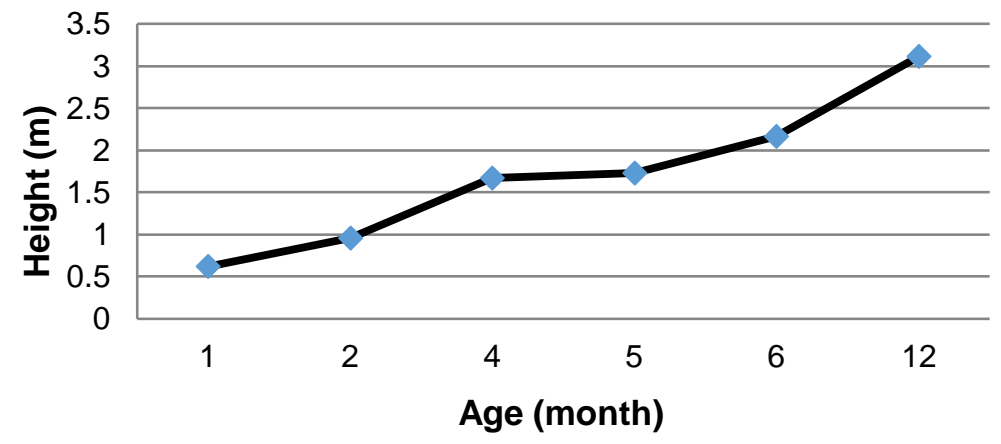

Fig. 3. Growth performance of the top five trees

Figure 4 shows the growth performance and survival rate of Leucaena after 12 months. The Leucaena trees showed a positive growth rate for the tree height. However, the survival rate after one year decreased up to $56 \%$, with a mean height of $2.0 \mathrm{~m}$. It clearly showed the effect of collecting wild seeds randomly from wilding trees and the need for improvement via breeding programs. Breeding programs involve incorporating selected wild trees into seed orchards and testing their progeny.

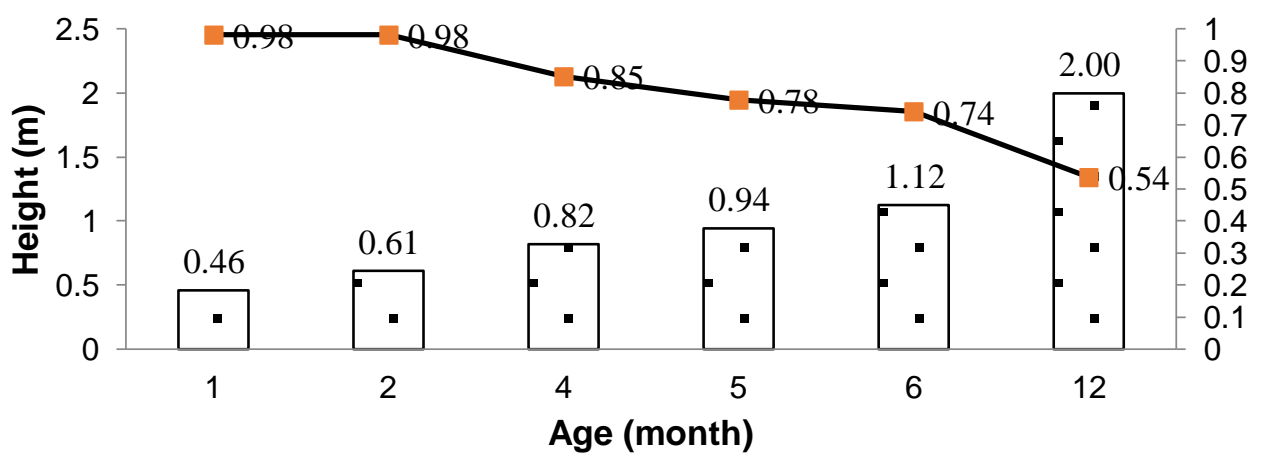

$\because$ Height Development $\quad-$-Survival Rate

Fig. 4. Growth performance and survival rate 
Although data about these trees is available, it is recommended for another program, such as a Genetic Improvement Program (gain $40 \%$ or lost 40\%), concerning Leucaena to be conducted in Malaysia. It is interesting to note that genetic improvements need to be done via breeding programs in the near future to produce maximum yields that are comparable to the yield potential of these species under optimum conditions in Malaysia. As a tree crop, Leucaena leucocephala is widely harvested for fuel, as well as pole and post wood. Improved varieties such as K636 encourage efforts to harvest lumber and paper pulp on a large plantation basis, with clear $30-\mathrm{cm}$ boles on $14-\mathrm{m}$ trees in 8 years. Silvicultural practice should include dense planting (e.g., 10000 stems/ha) with thinning for fuel wood at one year and three years, and harvest after six years to eight years (Brewbaker 1987). Reyes (1983) reported that field trials performed in Texas, USA have indicated that L. leucocephala cultivar K67 is promising for forage and woody biomass production. Although L. leucocephala is highly inbred and produces copious seeds in as little as 18 months, clonal in vitro propagation would be useful as most other Leucaena species are self-incompatible and produce few inbred (true to type) seeds (Brewbaker 1982). Hendrati and Nurrohmah (2019) in their studies looked at a separating distance of 10 to $100 \mathrm{~m}$ in between individual mother trees (families) in an attempt to avoid or reduce in- breeding. Rapid in vitro asexual propagation techniques would also be useful for promising hybrids, such as $L$. pulverulenta $\times$ L. leucocephala, and L. leucocephala $\times$ L. diversifolia, that have recently been made by tedious hand pollination techniques (Brewbaker 1982). Because of limited seed quantities from these hybrids, L. leucocephala K67 is used as a model for the genus. Many such hybrids are under evaluation at the University of Hawaii (Sorensson and Brewbaker 1994). The most focused for improvement of the species is the L. leucocephala (Lam.) de Wit (Brewbaker 2016).

Measurements of the tree height and stem diameter were conducted until the age of 12 months. At 4 months the height recorded was $0.82 \mathrm{~m}$ compared to the range 0.28 to $0.36 \mathrm{~m}$ for various breeds tested by Hendrati and Nurrohmah (2019). The recorded data showed that the largest tree had a height of $5.6 \mathrm{~m}$ and stem diameter of $7.9 \mathrm{~cm}$. Nevenimo and Bino (1998) reported that L. leucocephala can reach heights of $6.64 \mathrm{~m}$ within 19 months of growth. This showed that the growth conditions of Leucaena in Tawau, Malaysia are similar to those of Papua New Guinea, Brazil.

\section{Particleboard}

Since the 1980s, the Malaysian particleboard industry has depended on rubberwood as the main source of raw material. In this study, the combinations of the manufactured particleboard are varied to three of ratios of Leucaena leucocephala and rubberwood (20:80, 50:50, and 80:20). It was observed that a higher ratio of Leucaena in the particleboard imparted an increase in the mechanical strength (Table 1). As expected, generally higher resin contents in the particleboard produce better mechanical and physical properties, while a small amount of resin decreased the performances of particleboard. The values of thickness swelling could be improved if wax is used in the resin blend formulation. It is worth mentioning that the IB value is high and seemed to be reflected in trail run done by Muhammad Fitri et al. (2019) when plant parameters were used in production.

Statistical analysis of the particle board properties is given in Table 2. The analysis of variance (ANOVA) indicated highly significant difference for ratios (MOE, 
$\mathrm{IB}, \mathrm{TS}$ and WA) and resins (MOE, MOR, IB, TS, and WA). Interaction of the ratios and resins content are highly significant for all except IB (not significant).

Table 1. Mechanical and Physical Properties of Particleboard

\begin{tabular}{ccccccc}
\hline \multicolumn{1}{l}{$\begin{array}{c}\text { Ratio } \\
\text { LL:R }\end{array}$} & Resin & \multicolumn{5}{c}{ Means } \\
\cline { 3 - 7 } & $(\%)$ & $\begin{array}{c}\text { MOE } \\
(\mathrm{MPa})\end{array}$ & $\begin{array}{c}\text { MOR } \\
(\mathrm{MPa})\end{array}$ & $\begin{array}{c}\text { IB } \\
(\mathrm{MPa})\end{array}$ & $\begin{array}{c}\text { TS } \\
(\%)\end{array}$ & $\begin{array}{c}\text { WA } \\
(\%)\end{array}$ \\
\hline \hline $20: 80$ & 8 & 2641 & 20.07 & 0.56 & 26.05 & 82.16 \\
$20: 80$ & 10 & 3016 & 25.27 & 0.57 & 15.30 & 58.27 \\
$20: 80$ & 12 & 2835 & 23.73 & 0.67 & 17.96 & 74.34 \\
\hline $50: 50$ & 8 & 2354 & 16.78 & 0.67 & 20.22 & 76.45 \\
$50: 50$ & 10 & 3497 & 28.17 & 0.77 & 18.41 & 54.61 \\
$50: 50$ & 12 & 3266 & 27.53 & 0.76 & 15.30 & 66.21 \\
\hline $80: 20$ & 8 & 2265 & 16.53 & 0.58 & 16.86 & 78.71 \\
$80: 20$ & 10 & 3318 & 27.32 & 0.67 & 17.11 & 55.81 \\
$80: 20$ & 12 & 3362 & 27.50 & 0.99 & 13.66 & 53.54 \\
EN312:2003 & $\mathrm{P} 2$ & $>1800$ & $>13.00$ & $>0.40$ & - & - \\
\hline
\end{tabular}

Notes: LL:R - Leucaena leucocephala: rubberwood, MOE - Modulus of elasticity, MOR Modulus of rupture, IB - Internal bonding, TS - Thickness Swelling, and WA - Water Absorption

Table 2. Summary of ANOVA Analysis on Effects of Ratio and Resin Contents

\begin{tabular}{|c|c|c|c|c|c|c|}
\hline SOV & df & MOE & MOR & IB & TS & WA \\
\hline Ratios & 2 & $36.32^{* *}$ & $4.27^{\star}$ & $42.87^{\star *}$ & $163.03^{* *}$ & $36.17^{* *}$ \\
\hline Resins & 2 & $275.22^{\star *}$ & $186.78^{* *}$ & $12.43^{\star *}$ & $473.15^{\star *}$ & $59.04^{* *}$ \\
\hline Ratios* Resins & 4 & $9.66^{* *}$ & $6.93^{* *}$ & $2.12 \mathrm{~ns}$ & $17.32^{* *}$ & $5.21^{\star *}$ \\
\hline
\end{tabular}

Notes: ${ }^{* \star} \mathrm{F}$-values are highly significant $\mathrm{p}<0.01,{ }^{*} \mathrm{~F}$ - significant $\mathrm{p}<0.05$ and $\mathrm{ns}-$ not significant, $\mathrm{df}$ - Degree of freedom, MOE - Modulus of elasticity, MOR - Modulus of rupture, IB - Internal bonding, TS - Thickness Swelling and WA - Water Absorption

\section{Effects of Ratios}

The values for mechanical properties of particleboard with respect to ratios are shown in Fig. 5. All of the mechanical properties in Fig. 5 show increments in MOE, MOR, and IB. For MOE, the ratio of 20:80 had a significant difference from the other two ratios. Ratio 80:20 with MOE at $3024 \mathrm{MPa}$ was highest, but it was not significantly different from the ratio 50:50. The highest value of MOR was exibited by ratio 80:20 (23.37 MPa), while the smallest value was shown in particleboard with ratio 20:80 (22.12 $\mathrm{MPa})$. These values were significantly different. Figure 5 also shows values of $0.76,0.70$ and 0.56 MPa, for 80:20, 50:50, and 20:80, respectively, for IB, which are significantly different. The best IB performer of the particleboard was the ratio 80:20 with $12 \%$ resin at $0.99 \mathrm{MPa}$. The addition of a higher ratio of Leucaena leucocephala improved the strength of the particleboard in IB. The increasing amount of Leucaena leucocephala increased the mechanical properties on the board. Interestingly, this is opposite to work done by Loh et al. (2010), which showed declined strength when admixture of Mahang 
and rubberwood was used to produce particleboard compared to unmixed particle. The species used have differing impact towards performance of admixture particleboard.

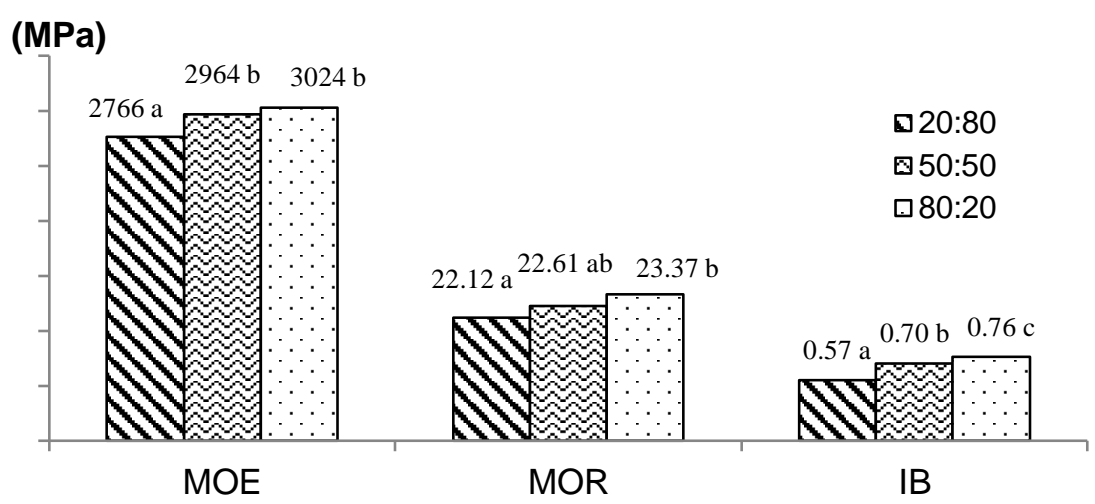

Fig. 5. Mechanical properties of paticleboard on ratios

Table 3 shows the Duncan's multiple range test (DMRT) results for ratios impact on TS and WA. Increasing ratio of Leucaena leucocephala on the manufacture of particleboard decreased the value of TS and WA. The difference was significant. The highest value of WA was for LL:R ratio 20:80, which registered $18 \%$ more absorption then LL:R 80:20. The trend for TS behavior was similar. Adding more Leucaena leucocephala in the manufacturing of the particleboard directly affected the physical properties of the particleboard. Treatment with higher Leucaena leucocephala than rubberwood possesses more capability to resist humidity.

Table 3. DMRT Results on Effect of Ratios on Thickness Swelling and Water Absorption

\begin{tabular}{|c|c|c|}
\hline Ratio & TS (\%) & WA (\%) \\
\hline $20: 80$ & $18.97 \mathrm{c}$ & $71.85 \mathrm{c}$ \\
\hline $50: 50$ & $16.10 \mathrm{~b}$ & $64.67 \mathrm{~b}$ \\
\hline $80: 20$ & $15.48 \mathrm{a}$ & $58.29 \mathrm{c}$ \\
\hline
\end{tabular}

Notes: TS - Thickness Swelling and WA - Water Absorption

\section{Effects of Resin Contents}

Figure 6 shows the mechanical properties of particleboard based on the effect of resin contents $(8,10$, and $12 \%)$. Modulus of elasticity shows good positive increment as resin content increase with the $12 \%$ resin contents having the highest value (3302 MPa). There were significant effects of three resin contents on MOE strength. The lowest value of MOE was achieved with $8 \%$ resin content (2501 MPa). The MOR values indicated a similar trend to MOE, and they were equally significantly different. The MOR for $12 \%$ resin was $44 \%$ higher than the \% resin. The MOR has directly proportional relationship to the resin contents used in the manufacturing of particleboard. Even though by performance there was an increment of IB as resin content increased, resin contents of $8 \%$ and $10 \%$ did not show significant IB difference. However, the IB of both resins 
content were significantly lower compared to $12 \%$ resin contents. Studies has shown strength of MOE, MOR, and IB are dependent on the amount of resin content used, as increasing of the amount of resin content could provide a more uniform coating of wood particles, thus encouraging better crosslinking (Ayrilmis et al. 2012; Sarmin et al. 2013)

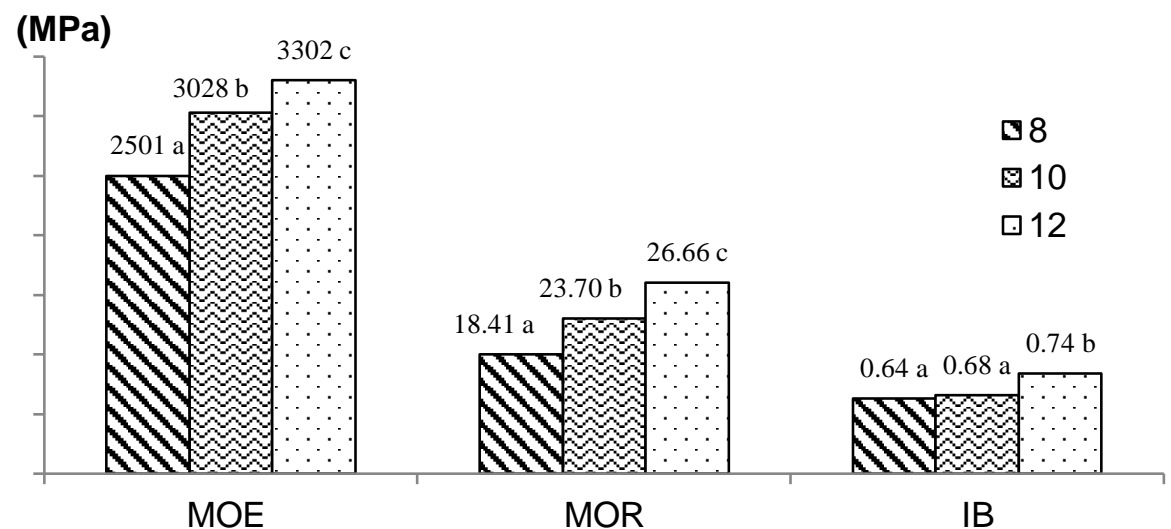

Fig. 6. Mechanical properties of particleboard on resin contents

In Table 4 the resin content is shown to have significant effects on the TS and WA properties of particleboard made. At $8 \%$ resin content, a TS value of $20.2 \%$ was the highest, while the lowest value was $13.9 \%$ (12\% resin contents). The value of TS decrease as the amount of resin content used increased The DMRT of WA showed that $10 \%$ and $12 \%$ had the same performance. At $8 \%$, the WA was significantly higher than the other two resin content. Higher used of resin content in the manufacturing of particleboard decreased the water absorption. This is due to the stronger bonding of resin and particle leading to less bulking in the board. The same result was also shown by Sarmin et al., (2013), where higher resin content reduced the properties of water absorption in particleboard.

Table 4. Summary of DMRT on Effect of Resin on Thickness Swelling and Water Absorption

\begin{tabular}{|c|c|c|}
\hline Resin Content (\%) & TS (\%) & WA (\%) \\
\hline 8 & $20.18 \mathrm{c}$ & $74.68 \mathrm{~b}$ \\
\hline 10 & $15.77 \mathrm{~b}$ & $58.78 \mathrm{a}$ \\
\hline 12 & $13.91 \mathrm{a}$ & $59.64 \mathrm{a}$ \\
\hline
\end{tabular}

Note: T S - Thickness Swelling and WA - Water Absorption 


\section{CONCLUSIONS}

1. The Leucaena trees showed positive growth rates for the tree height. However, in terms of the survival rate after one year, a decrease of up to $56 \%$ and a mean height of $2.0 \mathrm{~m}$ were noted. This observation showed the effect of wild seeds that are randomly collected from wilding and showcased that the seeds need to be improved or selected via breeding programs. The largest tree had a height of $5.6 \mathrm{~m}$ and stem diameter of $7.9 \mathrm{~cm}$.

2. For particleboards, Leucaena leucocephala was found to be a suitable alternative for particleboard manufacturing. All the boards passed EN312:2003 requirements, suitable for interior use such as furniture in dry conditions (Type P2). It is hoped that the results obtained in this early stage study can provide insight into adopting Leucaena for the wood-based industry in Malaysia.

\section{REFERENCES CITED}

Anis, M, Loh, Y. F., and Kamarudin, H. (2014). "Availability of oil palm trunk," Handbook of Oil Palm Trunk Plywood Manufacturing, Malaysia Timber Industry Board, Chap. 5, 1-15.

Ayrilmis, N., Kwon J. H., and Han, T. H. (2012). "Effect of resin type and content on properties of composite particleboard made of a mixture of wood and rice husk," International Journal of Adhesion \& Adhesives 38, 79-83.

Ashori, A., and Nourbakhsh, A. (2008). "Effect of press cycle time and resin content on physical and mechanical properties of particleboard panels made from the underutilized low-quality raw materials," Ind. Crop. Prod. 28(2), 225-230. DOI: 10.1016/j.indcrop.2008.02.015

Brewbaker, J. L. (1982). "Systematics, self-incompatibility, breeding systems and genetic improvement of Leucaena species," in: Leucaena Research in the Asian-Pacific Region, Singapore, Singapore, pp. 17-22.

Brewbaker, J. L. (1987). "Species in the genus Leucaena," Leucaena Research Report 7(2), 6-20.

Brewbaker, J. L. (2016). "Breeding Leucaena: Tropical multipurpose leguminous tree," Plant Breeding Reviews, Vol. 40, XL, $1^{\text {st }}$ Edition. Wiley-Blackwell, Inc., pp. 43-121.

EN 310 (1993). "Wood-based panels. Determination of modulus of elasticity in bending and of bending strength," European Committee for Standardization, Brussels, Belgium.

EN 312 (2003). "Particleboards - Specifications." European Committee for Standardization, Brussels, Belgium.

EN 317 (1993). "Particleboards and fibreboards. Determination of swelling in thickness after immersion in water," European Committee for Standardization, Brussels, Belgium.

EN 319 (1993). "Particleboards and fibreboards. Determination of tensile strength perpendicular to plane of the board," European Committee for Standardization, Brussels, Belgium.

Guler, C., Copur, Y., Akgul, M., and Buyuksari, U. (2007). "Some chemical, physical, and mechanical properties of juvenile wood from black pine (Pinus nigra Arnold) 
plantations," Journal of Applied Sciences 7(5), 755-758. DOI:

10.3923/jas.2007.755.758

Hendrati, R. L., and Nurrohmah, S. H. (2019). "Genetic improvement of Leucaena leucocephala for wood energy," Tropical Grasslands-Forrajes Tropicales 7(2), 210213.

Ishak, A. A., Karim, S. R. A., and Samsi, H. W. (2013). "Mechanical and physical properties of particle board made from silaned and $\mathrm{NaOH}$ modified kelampayan (Neolamarckia cadamba) particles," Adv. Mat. Res. 812, 169-174. DOI:

10.4028/www.scientific.net/AMR.812.169

Kasim, J. B., Yusof, A. A. M., Hashim, N. H. M., and Salamat, N. A. (2008). "Effects of particle sizes, resin content and board density on properties of Sesendok particleboard," Gading 12(1), 1-10.

Loh, Y. W., H`ng, P. S., Lee, S. H., Lum, W. C., and Tan, C. K. (2010). "Properties of particleboard produced from admixture of rubberwood and Mahang species," Asian Journal of Applied Sciences 3, 310-316.

Muhammad Fitri, S., Nor Yuziah, M. Y., Hilmi, A. R., and Wan Mohd Nazri, W. A. R. (2019). “Leucaena particleboard: A commercial trial," BioResources 14 (2), 35063511. DOI: 10.15376/biores.14.2.3506-3511

Nevenimo, T., and Bino, B. (1998). "Growth performance of nitrogen fixing tree species in Papua New Guinea," in: Forest, Farm, and Community Tree Research ReportsSpecial Issue, Winrock International, Little Rock, AR, pp. 55-64.

Oggiano, N., Angelini, L. G., and Cappelletto, P. (1997). "Pulping and paper properties of some fibre crops," Ind. Crop. Prod. 7(1), 59-67. DOI: 10.1016/S09266690(97)00071-X

Reyes, I. (1983). Evaluation of Leucaena Forage and Biofuel Potential in Semi-Arid South Texas, Master's Thesis, Texas A\&I University, Kingsville, TX.

Sarmin, S. N., Zakaria, S. A. K. Y., and Kasim, J. (2013). "Mechanical properties of homogeneous and heterogeneous three layered particleboard composite in relation on different resin content," Adv. Mat. Res. 699, 637-640. DOI: 10.4028/www.scientific.net/AMR.699.637

Sorensson, C. T., and Brewbaker, J. L. (1994). "Interspecific compatibility among 15 Leucaena species (Leguminosae: Mimosoideae) via artificial hybridization," Am. J. Bot. 81(2), 240-247. DOI: 10.1002/j.1537-2197.1994.tb15435.x

Wan Abd Rahman, W. M. N., Md Yatim, A., Mat Zlan, A., Kasim, J., and Mohd Yunus, N. Y. (2019). "Effects of the resin content and particle size on the properties of particleboard made of Neolamarckia and Leucaena particles," BioResources 14(3), 6079-6087. DOI: 10.15376/biores.14.3.6079-6087

Zhang, Y., Gu, J., Tan, H., Di, M., Zhu, L., and Weng, X. (2011). "Straw based particleboard bonded with composite adhesives," BioResources 6(1), 464-476. DOI: 10.15376/biores.6.1.464-476

Article submitted: April 30, 2020; Peer review completed: May 31, 2020; Revised version received and accepted: August 4, 2020; Published: August 7, 2020.

DOI: $10.15376 /$ biores.15.4.7433-7442 